\title{
Validation of an HPLC Method for the Simultaneous Quantification of Metabolic Reaction Products Catalysed by CYP2C11 Enzymes in Rat Liver Microsomes: In Vitro Inhibitory Effect of Salicylic Acid on CYP2C11 Enzyme
}

\author{
Hassan Salhab*(D), Declan P. Naughton and James Barker $\mathbb{D}$ \\ School of Life Sciences, Pharmacy and Chemistry, Kingston University, Kingston upon Thames, \\ London KT1 2EE, UK; d.naughton@kingston.ac.uk (D.P.N.); j.barker@kingston.ac.uk (J.B.) \\ * Correspondence: K1542808@kingston.ac.uk; Tel.: +447984974741; Fax: +442084179000
}

Academic Editor: Makoto Tsunoda

Received: 1 October 2019; Accepted: 20 November 2019; Published: 25 November 2019

\begin{abstract}
The inhibitory effect of new chemical entities on rat liver P450 marker activities was investigated in a functional approach towards drug development. Treatment of colorectal cancer (CRC) and chemoprevention using salicylic acid has gained a lot of attention, mainly in the prevention of the onset of colon cancer. Thus, an in vitro inhibitory effect of salicylic acid on rat CYP2C11 activity was examined by using high performance liquid chromatography (HPLC). High performance liquid chromatography analysis of a CYP2C11 assay was developed on a reversed phase $\mathrm{C}_{18}$ column (SUPELCO $25 \mathrm{~cm} \times 4.6 \mathrm{~mm} \times 5 \mu \mathrm{m}$ ) at $243 \mathrm{~nm}$ using $32 \%$ phosphate buffer ( $\mathrm{pH} 3.36$ ) and $68 \%$ methanol as a mobile phase. The CYP2C11 assay showed good linearity for all components $\left(R^{2}>0.999\right)$. Substrates and metabolites were found to be stable for up to $72 \mathrm{~h}$. Additionally, the method demonstrated good reproducibility, intra- and inter-day precision $(<15 \%)$, acceptable recovery and accuracy $(80 \%-120 \%)$, and low detection $(1.3501 \mu \mathrm{M}$ and $3.2757 \mu \mathrm{M})$ and quantitation limit values $(4.914 \mu \mathrm{M}$ and $9.927 \mu \mathrm{M})$ for $16 \alpha$-hydroxytestosterone and testosterone, respectively. Salicylic acid acts reversibly as a noncompetitive (weak) inhibitor with $\mathrm{K}_{\mathrm{i}}=84.582 \pm 2.67 \mu \mathrm{M}$ (concentration of inhibitor to cause $50 \%$ inhibition of original enzyme activity $\left(\mathrm{IC}_{50}\right)=82.70 \pm 2.67 \mu \mathrm{M}$ ) for CYP2C11 enzyme activity. This indicates a low potential to cause toxicity and drug-drug interactions.
\end{abstract}

Keywords: cytochrome P450; HPLC; 16 $\alpha$-hydroxytestosterone; phenacetin; salicylic acid; testosterone

\section{Introduction}

Cytochrome P450s are known as Phase 1 mono-oxygenase drug-mediated enzymes that play a vital role as a body defence in the drug pharmacokinetic field [1]. Cytochrome P450s have the ability to transform biologically xenobiotic drugs, such as steroids, fatty acid derivatives, hormones, and endogenous and exogenous molecules, into more lipophobic molecules (more polar functional groups) [2]. CYP450 drug metabolising enzymes are located predominantly in the liver, whereas a few of them are expressed in other human body organs, such as the small intestine, kidneys, lungs and placenta [3]. Statistical results have shown that about $70 \%-80 \%$ of most marketed drugs are metabolised by five major Phase 1 drug mediated enzymes [4].

Nowadays, toxicity and bioavailability issues are the most common obstacles in the drug development field [4]. Therefore, induction or inhibition of CYP450 enzymes can result in either drug-drug or drug-herb interactions, and their effectiveness can be altered [5]. Thus, this leads to a therapeutic failure in the treatment [3]. Understanding the concept of inhibition and induction 
pathways can help in reducing the interaction between drugs and occurrence of adverse reactions [3]. Inhibition of CYP450 enzymes by drugs can lead to a rise in the concentration of other metabolising drugs, thus causing drug toxicity problems [6].

The CYP2C11 isoform is the most dominant isoform in male-specific rat liver microsomes and accounts for $50 \%$ of the total male-specific male rat hepatocytes [7]. Wojcikowski et al. [7] stated that testosterone is metabolised to either $16 \alpha$-hydroxytestosterone or $2 \alpha$-hydroxytestosterone by means of CYP2C11 enzyme activity in male-specific rat liver microsomes. Previous studies showed that some inflammatory mediators, such as ethanol, cimetidine and diclofenac, extensively inhibit the CYP2C11 isoform [7]. Thus, both $2 \alpha$ and 16 $\alpha$-hydroxytestosterone are used as markers in studying CYP2C11 enzyme activity in rat liver microsomes [7].

Salicylic acid (Figure 1) belongs to a nonsteroidal, anti-inflammatory drug class, which plays a vital role in the reduction of gastrointestinal tumours [8]. However, recent studies revealed that salicylic acid can cause liver damage [9]. These studies have shown that salicylic acid can be metabolised to six metabolites using various quantitative analytical techniques, such as HPLC and liquid chromatography tandem mass spectrometry (LC-MS/MS) [10]. Salicylic acid inhibits the metabolism of fatty acid based on the acyl chain length [11]. These studies suggested that salicylic acid can be linked to the interference of fatty acid metabolism by reducing [C14] $\mathrm{CO}_{2}$ from fatty acid and increasing the amount of uncoupled fatty acid in the plasma. Until now, various papers on the pharmacokinetics and metabolism of salicylic acid have been reported, but only one paper [9] has shown that the oxidative metabolism of salicylic acid is mediated by CYP2E1 and CYP2C11 enzymes in rat liver microsomes.

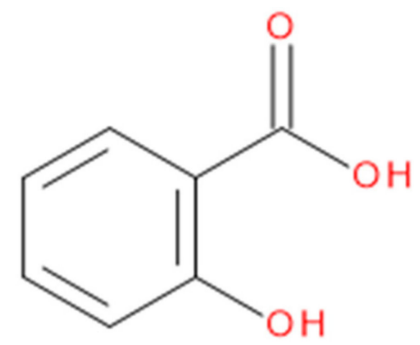

Figure 1. Structure of salicylic acid.

Consequently, an analytical HPLC method was validated, which studies the in vitro inhibitory effect of salicylic acid on the activities of major cytochrome CYP450s (CYP2C11) as an example for promoting the safety and efficacy of salicylic acid in clinics.

\section{Results and Discussion}

\subsection{Selection of Analytical Wavelength: UV-VIS (Ultraviolet-Visible) Spectroscopy (CYP2C11 Assay)}

UV-VIS spectrophotometry analysis for CYP2C11 assay was performed by dissolving salicylic acid $(100 \mu \mathrm{M})$, testosterone $(200 \mu \mathrm{M})$ and $16-\alpha$ hydroxytestosterone $(50 \mu \mathrm{M})$ powder in pure methanol (wavelength cut-off of methanol was $210 \mathrm{~nm}$ ).

The following graph illustrates the measurements of maximum wavelength of each component in the CYP2C11 assay.

From overlain spectra of CYP2C11 assay compounds (Figure 2) and (Figure S1), it is shown that the maximum of the absorption band for all four CYP2C11 components is $243 \mathrm{~nm}$, and so this was chosen for our study. 


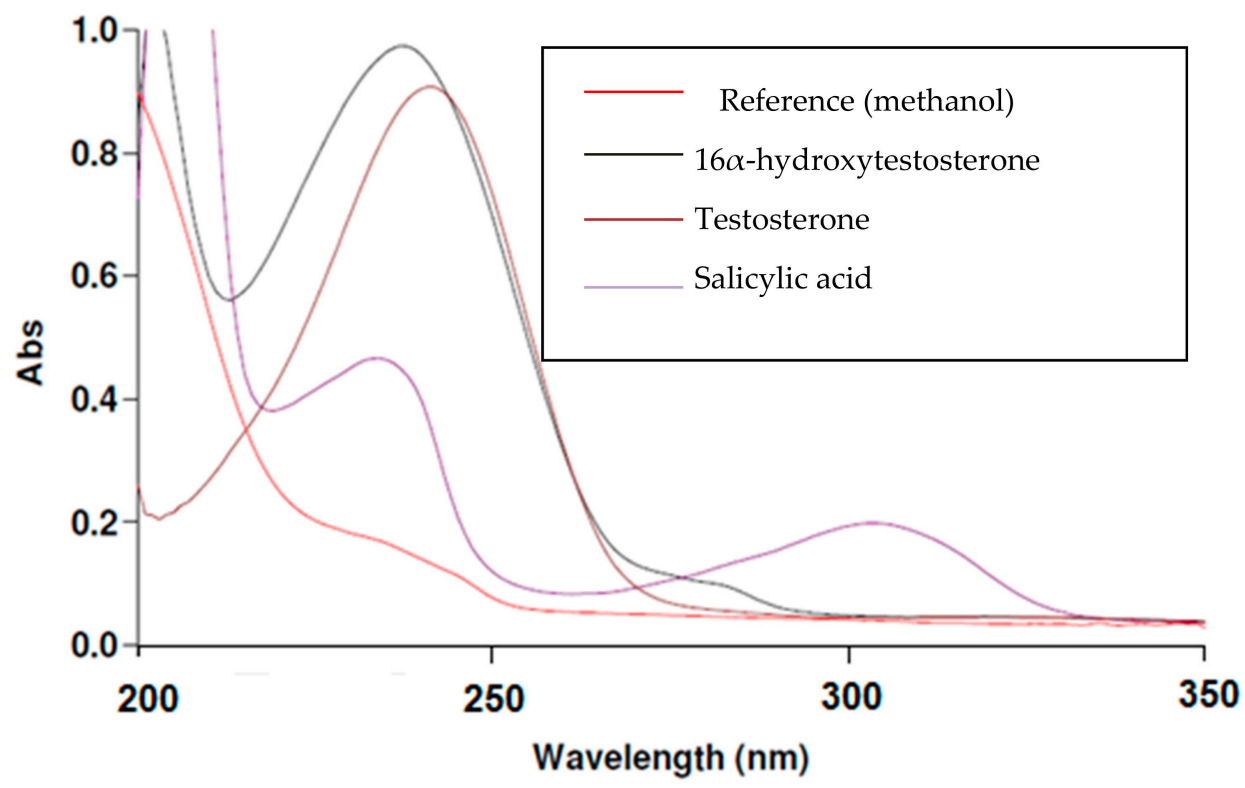

Figure 2. Overlain spectra of salicylic acid, testosterone and $16 \alpha$-hydroxytestosterone components in the CYP2C11 assay.

\subsection{Method Validation}

\subsubsection{Linearity and Range}

Different concentrations of testosterone and its metabolite (16 $\alpha$-hydroxytestosterone) solutions (mentioned in Section 3.6.1) were analysed by HPLC for the production of standard calibration curves. Calibration curves were constructed by plotting the mean area peak of standards and phenacetin (internal standard) versus the concentration of standard (substrate and metabolite). The outcomes are listed in Table 1. Good linearities for both testosterone and 16 $\alpha$-hydroxytestosterone were obtained, with $r^{2}$ values of 0.9999 and 0.9998 , respectively. The linear regression coefficient was within the acceptable range $\left(r^{2}>0.99\right)$, according to ICH (International Conference on Harmonization) guidelines. Relative standard deviations (\%RSD) at each different concentration $(<5 \%)$ met the ICH guidelines [12].

Table 1. Analytical performances.

\begin{tabular}{ccc}
\hline Standards & Testosterone & 16 $\alpha$-hydroxytestosterone \\
\hline Regression equation & $\mathrm{Y}=0.0189 \mathrm{X}-0.0203$ & $\mathrm{Y}=0.0204 \mathrm{X}-0.0036$ \\
$r^{2}$ & 0.9999 & 0.9998 \\
Linear range & $10-400 \mu \mathrm{M}$ & $10-100 \mu \mathrm{M}$ \\
\hline
\end{tabular}

\subsubsection{Limit of Detection (LOD) and Limit of Quantitation (LOQ)}

According to ICH Technical Requirements for Registration of Pharmaceuticals for Human Use, the LOD and LOQ of the proposed method were calculated mathematically by the relationship between the slope of the calibration curve and the standard deviation of the response using the following equations

$$
\mathrm{LOD}=3.3 \sigma / \mathrm{S} \quad \mathrm{LOQ}=10 \sigma / \mathrm{S}
$$

where $\sigma$ is the standard deviation of the response; $S$ is the slope of the calibration curve.

The results presented in Table 2 demonstrate that both testosterone and $16 \alpha$-hydroxytestosterone have detection values in the range of $1-4 \mu \mathrm{M}$ and quantitation values in the range of $4-10 \mu \mathrm{M}$, which is consistent with the literature [13]. 
Table 2. Limit of detection (LOD) and limit of quantitation (LOQ) for testosterone and $16 \alpha$-hydroxytestosterone.

\begin{tabular}{ccc}
\hline Standards & Testosterone & 16 $\boldsymbol{\alpha}$-hydroxytestosterone \\
\hline Limit of Detection (LOD) & $3.276 \mu \mathrm{M}$ & $1.350 \mu \mathrm{M}$ \\
Limit of Quantitation (LOQ) & $9.927 \mu \mathrm{M}$ & $4.914 \mu \mathrm{M}$ \\
\hline
\end{tabular}

\subsubsection{Specificity and Selectivity}

Specificity tests were performed by using spiked samples (50 $\mu \mathrm{M}$ of phenacetin dissolved in 30\% of phosphate buffer ( $\mathrm{pH} 3.36)+70 \%$ of methanol) to evaluate that the method outcomes were not affected by the impurities.

Specificity was achieved by choosing the right mobile phase composition (phosphate buffer at $\mathrm{pH} 3.36(\mathrm{~A})+$ methanol (B)) using low pressure isocratic elution programming: $68 \%$ methanol + $32 \%$ phosphate buffer at $\mathrm{pH}=3.36$. This results in good separation of the enzyme peak (NADPH (Nicotinamide Adenine Dinucleotide Phosphate Hydrogen)-regenerating system) from the CYP2C11 metabolite (16 $\alpha$-hydroxytestosterone), salicylic acid, phenacetin and testosterone peaks at $\mathrm{T}=25^{\circ} \mathrm{C}$, using a C18 (SUPELCO $25 \mathrm{~cm} \times 4.6 \mathrm{~mm}, 5 \mu \mathrm{m}$ ) column at $0.8 \mathrm{~mL} / \mathrm{min}$ flow rate and a wavelength of $\lambda=243 \mathrm{~nm}$ (Figure 3).

$\mathrm{mV}$

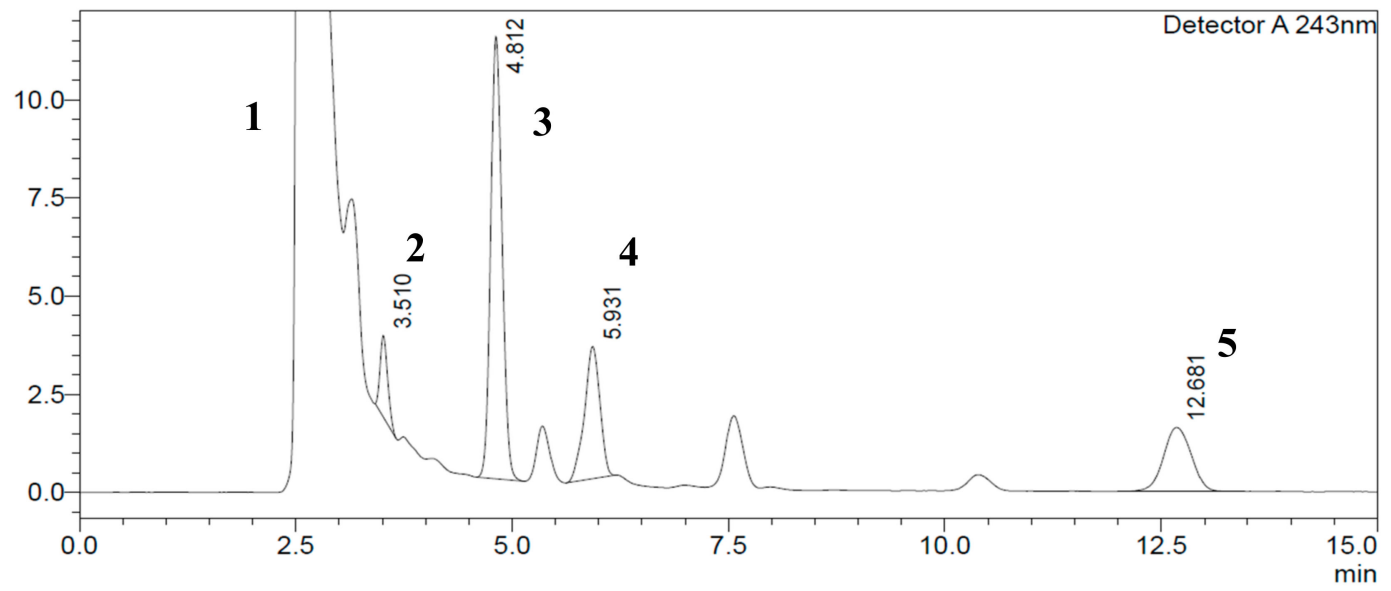

Figure 3. Typical HPLC chromatogram of CYP2C11 components in standard rat microsomal medium at $243 \mathrm{~nm}$ wavelength detection and a concentration of $150 \mu \mathrm{M}$ testosterone. The peaks marked are: (1) NADPH (Nicotinamide Adenine Dinucleotide Phosphate Hydrogen)-regenerating system; (2) salicylic acid (100 $\mu \mathrm{M})$; (3) phenacetin; (4) 16 $\alpha$-hydroxytestosterone; and (5) testosterone respectively.

\subsubsection{Precision}

Intra-Assay Variation of Testosterone and $16 \alpha$-hydroxytestosterone

Intra-assay variation of testosterone and $16 \alpha$-hydroxytestosterone was determined by measuring three testosterone concentration levels $(200,100$, and $25 \mu \mathrm{M}$, representing high, medium, and low levels, respectively) and three $16 \alpha$-hydroxytestosterone concentration levels $(80,40,10 \mu \mathrm{M}$, representing high, medium, and low levels, respectively) 3 times in a single batch $(n=3)$. The outcomes, summarised in Tables 3 and 4, illustrate that the \%RSD (relative standard deviation) was $<5 \%$ for testosterone and $16 \alpha$-hydroxytestosterone. The experiment revealed that there is no significant variation in intra-assay measurements. 
Table 3. Intra-assay variation for testosterone $(n=3)$.

\begin{tabular}{cccc}
\hline Testosterone Standard & Mean Activity ${ }^{\mathbf{a}}(\boldsymbol{\mu M})$ & Standard Deviation & Relative Standard Deviation $(\%)$ \\
\hline Low-activity standard $(\mathrm{C}=25 \mu \mathrm{M})$ & 22.8856 & 0.4851 & 2.1198 \\
Medium-activity standard $(\mathrm{C}=100 \mu \mathrm{M})$ & 102.7028 & 0.6444 & 0.6275 \\
High-activity standard $(\mathrm{C}=200 \mu \mathrm{M})$ & 201.2282 & 4.9342 & 2.4520 \\
\hline
\end{tabular}

${ }^{a}$ Mean found concentration $(\mu \mathrm{M})$.

Table 4. Intra-assay variation for $16 \alpha$-hydrotestosterone $(n=3)$.

\begin{tabular}{cccc}
\hline $\mathbf{1 6} \alpha$-hydroxytestosterone Standard & Mean Activity ${ }^{\mathbf{a}}(\boldsymbol{\mu M})$ & Standard Deviation & Relative Standard Deviation $(\%)$ \\
\hline Low-activity standard $(\mathrm{C}=10 \mu \mathrm{M})$ & 8.5631 & 0.3848 & 4.4946 \\
Medium-activity standard $(\mathrm{C}=40 \mu \mathrm{M})$ & 31.0608 & 0.3516 & 1.1322 \\
High-activity standard $(\mathrm{C}=80 \mu \mathrm{M})$ & 67.9271 & 0.2154 & 0.3172 \\
\hline
\end{tabular}

${ }^{a}$ Mean found concentration $(\mu \mathrm{M})$.

Inter-Assay Variation of Testosterone and 16 $\alpha$-hydroxytestosterone

Inter-assay variation was determined by measuring testosterone standards of three concentrations levels (200, 100, and $25 \mu \mathrm{M}$, representing high, medium, low levels, respectively) and $16 \alpha$-hydroxytestosterone $(80,40,10 \mu \mathrm{M})$ for three consecutive days, in separate batches. The results, summarised in Tables 5 and 6, illustrate that the relative standard deviation or \%RSD was $<10 \%$ for testosterone and 16 $\alpha$-hydroxytestosterone. The experiment revealed that there is no significant variation between aliquots of the same batch sample in inter-assay measurements.

Table 5. Inter-assay variation for testosterone.

\begin{tabular}{|c|c|c|c|c|c|}
\hline \multicolumn{2}{|c|}{ Testosterone Standard $(\mu \mathrm{M})$} & $\begin{array}{c}\text { Mean Area Peak } \\
(\mathrm{n}=3 \text { each Level) }\end{array}$ & $\begin{array}{c}\text { Mean }^{\text {a }} \\
\text { Activity }(\mu \mathrm{M})\end{array}$ & $\begin{array}{l}\text { Standard } \\
\text { Deviation }\end{array}$ & $\begin{array}{c}\text { Relative Standard } \\
\text { Deviation (\%) }\end{array}$ \\
\hline \multirow{3}{*}{$\begin{array}{l}\text { Low-activity standard } \\
\qquad(\mathrm{C}=25 \mu \mathrm{M})\end{array}$} & Day 1 & 0.7057 & \multirow{3}{*}{24.3194} & \multirow{3}{*}{0.6826} & \multirow{3}{*}{2.8068} \\
\hline & Day 2 & 0.5725 & & & \\
\hline & Day 3 & 0.8314 & & & \\
\hline \multirow{3}{*}{$\begin{array}{l}\text { Medium-activity } \\
\text { standard } \\
(\mathrm{C}=100 \mu \mathrm{M})\end{array}$} & Day 1 & 2.9393 & \multirow{3}{*}{101.7997} & \multirow{3}{*}{2.0495} & \multirow{3}{*}{2.0133} \\
\hline & Day 2 & 2.3360 & & & \\
\hline & Day 3 & 3.4765 & & & \\
\hline \multirow{3}{*}{$\begin{array}{l}\text { High-activity standard } \\
\qquad(\mathrm{C}=200 \mu \mathrm{M})\end{array}$} & Day 1 & 5.9357 & \multirow{3}{*}{210.938} & \multirow{3}{*}{8.8989} & \multirow{3}{*}{4.2187} \\
\hline & Day 2 & 4.8596 & & & \\
\hline & Day 3 & 7.3105 & & & \\
\hline
\end{tabular}

Table 6. Inter-assay performance of $16 \alpha$-hydroxytestosterone.

\begin{tabular}{cccccc}
\hline $\begin{array}{c}\mathbf{1 6} \boldsymbol{\alpha} \text {-hydroxytestosterone Standard } \\
(\mu \mathrm{M})\end{array}$ & $\begin{array}{c}\text { Mean Area Peak } \\
(\mathbf{n}=\mathbf{3} \text { each level) }\end{array}$ & $\begin{array}{c}\text { Mean }{ }^{\mathrm{a}} \\
\text { Activity }(\boldsymbol{\mu M})\end{array}$ & $\begin{array}{c}\text { Standard } \\
\text { Deviation }\end{array}$ & $\begin{array}{c}\text { Relative Standard } \\
\text { Deviation (\%) }\end{array}$ \\
\hline Low-activity standard & Day 1 & 0.1932 & & & \\
$(\mathrm{C}=10 \mu \mathrm{M})$ & Day 2 & 0.3154 & 10.5557 & 0.7102 & 6.7286 \\
Medium-activity & Day 3 & 0.1227 & & & \\
standard & Day 1 & 0.7802 & & & \\
$(\mathrm{C}=40 \mu \mathrm{M})$ & Day 2 & 1.2850 & 38.1011 & & \\
High-activity standard & Day 3 & 0.4912 & & & \\
$(\mathrm{C}=80 \mu \mathrm{M})$ & Day 1 & 1.6356 & & & \\
& Day 2 & 2.6480 & 79.7765 & 2.4168 & \\
& Day 3 & 1.1200 & &
\end{tabular}

\subsubsection{Stability Test}

\section{Stability Test of Testosterone}

The stability of testosterone was investigated at three different concentrations $(25,100$, and $200 \mu \mathrm{M}$, representing low, medium and high levels, respectively), which were chosen as an approximation of its $\mathrm{K}_{\mathrm{m}}$ [14], and stored for $72 \mathrm{~h}$ at room temperature in natural light conditions. Phenacetin (as an internal standard of $50 \mu \mathrm{M})$ was added to each batch. Samples were analysed in triplicate $(\mathrm{n}=3)$ for each batch. The stability test results are summarised in Table 7. 
Table 7. Stability test data for testosterone.

\begin{tabular}{ccccc}
\hline & \multicolumn{4}{c}{ Nominal Level (Actual Concentration of Testosterone $(\boldsymbol{\mu M}))$} \\
\cline { 2 - 5 } & & $\mathbf{2 5}$ & $\mathbf{1 0 0}$ & $\mathbf{2 0 0}$ \\
\hline \multirow{2}{*}{ Calculated concentration } & $24 \mathrm{~h}$ & 20.0423 & 80.1101 & 159 \\
$(\boldsymbol{\mu M})$ & $48 \mathrm{~h}$ & 21.6355 & 80.1101 & 159 \\
& $72 \mathrm{~h}$ & 21.4054 & 86.0148 & 162.3135 \\
\% Recovery $^{\mathbf{a}}$ & $24 \mathrm{~h}$ & 107.9492 & 100 & 163.3444 \\
& $48 \mathrm{~h}$ & 107.5323 & 107.3707 & 102.0839 \\
& $72 \mathrm{~h}$ & 106.8007 & 99.8624 & 102.7323 \\
Accuracy $^{\mathbf{b}} \mathbf{( \% )}$ & $0 \mathrm{~h}$ & 119.8305 & 119.8898 & 120.5 \\
& $24 \mathrm{~h}$ & 113.4576 & 119.8898 & 120.5 \\
& $48 \mathrm{~h}$ & 113.7918 & 113.9851 & 118.8432 \\
& $72 \mathrm{~h}$ & 114.3783 & 120 & 118.3277 \\
\hline
\end{tabular}

Note: ${ }^{a} \%$ recovery $=$ (concentration of testosterone at $24 \mathrm{~h} /$ standard concentration of testosterone $) \times 100$;

$\mathrm{b}$ Accuracy $=100-(($ calculated concentration - actual concentration $) /$ actual concentration $) \times 100$.

The outcomes revealed that there was no variation in the concentration or changes in chromatographic behavior of testosterone at $0,24,48$, and $72 \mathrm{~h}$, compared to actual concentrations. Calibration curves were plotted for days 1-4 and all four calibration curves were averaged, hence the average calibration curve equation was: $y=0.0236 x-0.0406\left(R^{2}=0.9997\right)$, where $r^{2}$ met ICH guidelines. LOD and LOQ values were 5.4408 and $16.4874 \mu \mathrm{M}$, respectively. Percentage recovery for testosterone at concentrations of 25,100 and $200 \mu \mathrm{M}$ was found to be within an acceptable range $(80 \%-120 \%)$, according to ICH guidelines, and thus the results show high and acceptable accuracy $(80 \%-120 \%)$ for testosterone concentrations of 25 and $100 \mu \mathrm{M}$. On the other hand, at $200 \mu \mathrm{M}$ concentration, the accuracy was just beyond the acceptable value of $120.5 \%$ for 0 and $24 \mathrm{~h}$. The results indicate that testosterone solution was relatively stable for $72 \mathrm{~h}$ at ambient temperature, which is consistent with the literature [15].

Stability Test of $16 \alpha$-hydroxytestosterone

Stability of CYP2C11 metabolite (16-alfa hydroxytestosterone) was investigated for three different concentrations $(10,40$, and $80 \mu \mathrm{M})$ stored for $72 \mathrm{~h}$ and kept at room temperature in natural light conditions. Three different concentration ranges of 16-alfa hydroxytestosterone were chosen, since the amount of metabolite formed at $200 \mu \mathrm{M}$ of testosterone was $35 \mu \mathrm{M}$, meaning it was necessary to investigate the stability of the metabolite at low, medium, and high concentrations. Phenacetin (as an internal standard of $50 \mu \mathrm{M})$ was added to each batch. The sample was analysed in triplicate $(n=3)$ for each batch. The stability test results are summarised in Table 8 . 
Table 8. Stability test data of 16-alfa hydroxytestosterone.

\begin{tabular}{|c|c|c|c|c|}
\hline & \multicolumn{4}{|c|}{ Nominal Level (Actual Concentration of 16-alfa Hydroxytestosterone $(\mu \mathrm{M})$ ) } \\
\hline & & 10 & 40 & 80 \\
\hline \multirow{4}{*}{$\begin{array}{c}\text { Calculated concentration } \\
\qquad(\mu \mathrm{M})\end{array}$} & $0 \mathrm{~h}$ & 10.533 & 38.0055 & 77.5659 \\
\hline & $24 \mathrm{~h}$ & 10.9725 & 41.3021 & 88.5549 \\
\hline & $48 \mathrm{~h}$ & 11.1923 & 44.2142 & 91.8516 \\
\hline & $72 \mathrm{~h}$ & 10.4 & 35.0866 & 76.5 \\
\hline \multirow{3}{*}{$\%$ Recovery $^{a}$} & $24 \mathrm{~h}$ & 109.725 & 103.2552 & 110.6936 \\
\hline & $48 \mathrm{~h}$ & 111.923 & 110.5355 & 114.8145 \\
\hline & $72 \mathrm{~h}$ & 104 & 87.7165 & 95.625 \\
\hline \multirow{4}{*}{ Accuracy ${ }^{b}(\%)$} & $0 \mathrm{~h}$ & 94.67 & 104.9862 & 103.0426 \\
\hline & $24 \mathrm{~h}$ & 90.275 & 96.7448 & 89.3064 \\
\hline & $48 \mathrm{~h}$ & 88.077 & 89.4645 & 85.1855 \\
\hline & $72 \mathrm{~h}$ & 96 & 112.2835 & 104.375 \\
\hline
\end{tabular}

Note: ${ }^{\text {a }} \%$ recovery $=($ concentration of testosterone at $24 \mathrm{~h} /$ standard concentration of testosterone $) \times 100$.

b Accuracy $=100-(($ calculated concentration - actual concentration $) /$ actual concentration $) \times 100$.

The results presented in Table 8 show that there was no variation in the concentration or in changes in chromatographic behaviour of 16-alfa hydroxytestosterone at $0,24,48$ and $72 \mathrm{~h}$ compared to actual concentrations. Calibration curves were plotted for days 1-4 and all four calibration curves were averaged, hence the average calibration curve equation was: $y=0.0182 x-0.0117\left(r^{2}=0.9992\right)$, where $\mathrm{r}^{2}$ met the ICH guidelines. Percentage recovery for 16-alfa hydroxytestosterone at concentrations of 10 , 40 and $80 \mu \mathrm{M}$ was found to be within acceptable ranges $(80 \%-120 \%)$, according to ICH guidelines. Thus, the results show high and acceptable accuracy $(80 \%-120 \%)$ for 16 -alfa hydroxytestosterone concentrations of 10,40 and $80 \mu \mathrm{M}$ compared with the standard known concentration. Therefore, the results indicate that 16-alfa hydroxytestosterone solution was stable for $72 \mathrm{~h}$ at room temperature, which is consistent with the literature [16].

\subsubsection{Robustness Test}

Changing the Percentage of the Mobile Phase

A robustness study was performed by changing the percentage of the mobile phase (increasing the percentage of methanol by $2 \%$ ) using HPLC, and evaluating the effect on retention time and peak area of each compound. Table 9 shows the change in mobile phase ratio on both retention time and peak area of each compound.

Table 9. Retention time, peak area and resolution variation upon using two different mobile phase composition modes at a flow rate of $0.8 \mathrm{~mL} / \mathrm{min}$.

\begin{tabular}{|c|c|c|c|c|}
\hline $\begin{array}{l}\text { Mobile Phase } \\
\text { Composition }\end{array}$ & Compounds & $\begin{array}{l}\text { Average Retention } \\
\text { Time }(\mathrm{n}=3)(\mathrm{min})\end{array}$ & $\begin{array}{l}\text { Average Area Peak } \\
(\mathrm{n}=3) \text { (Arb units) }\end{array}$ & Resolution \\
\hline \multirow{4}{*}{$\begin{array}{c}70 \% \text { Methanol }+ \\
30 \% \text { Phosphate } \\
\text { buffer at } \mathrm{pH}=3.36\end{array}$} & Salicylic acid $(100 \mu \mathrm{M})$ & 3.468 & 63443 & \multirow{4}{*}{$\begin{array}{l}16 \alpha \text {-hydroxytestosterone and phenacetin } \\
\text { were well separated (good resolution) } \\
\text { (Difference in retention time }=0.842 \mathrm{~min} \text { ). }\end{array}$} \\
\hline & Phenacetin $(50 \mu \mathrm{M})$ & 4.512 & 143502 & \\
\hline & Testosterone $(200 \mu \mathrm{M})$ & 10.726 & 644120 & \\
\hline & $\begin{array}{c}16 \alpha \text { - hydroxytestosterone } \\
(50 \mu \mathrm{M})\end{array}$ & 5.354 & 222620 & \\
\hline \multirow{4}{*}{$\begin{array}{c}68 \% \text { Methanol }+ \\
32 \% \text { Phosphate } \\
\text { buffer at } \mathrm{pH}=3.36\end{array}$} & Salicylic acid $(100 \mu \mathrm{M})$ & 3.572 & 67994 & \multirow{4}{*}{$\begin{array}{l}\text { 16 } \alpha \text {-hydroxytestosterone and phenacetin } \\
\text { were well separated from each other } \\
\text { (very good resolution) } \\
\text { (Difference in retention time }=1.083 \mathrm{~min} \text { ). }\end{array}$} \\
\hline & Phenacetin $(50 \mu \mathrm{M})$ & 4.730 & 141116 & \\
\hline & Testosterone $(200 \mu \mathrm{M})$ & 12.359 & 641325 & \\
\hline & $\begin{array}{l}16 \alpha \text { - hydroxytestosterone } \\
(50 \mu \mathrm{M})\end{array}$ & 5.813 & 216239 & \\
\hline
\end{tabular}

Overall, retention time, peak area and resolution for salicylic acid, phenacetin, testosterone and $16 \alpha$-hydroxytestosterone did not vary when changing the composition of methanol by $2 \%$, except that testosterone eluted later $\left(t_{R}=12.359 \mathrm{~min}\right)$ when the concentration of methanol decreased by $2 \%$. This means that testosterone is more soluble in organic solvent than aqueous medium. A mobile phase consisting of $68 \%$ methanol with $32 \%$ phosphate buffer at $\mathrm{pH} 3.36$ was chosen because the resolution 
between phenacetin and 16-alfa hydroxytestosterone peaks (1.083 $\mathrm{min})$ was greater than the resolution between phenacetin and 16-alfa hydroxytestosterone peaks $(0.842 \mathrm{~min})$ when using $70 \%$ methanol with $30 \%$ phosphate buffer at $\mathrm{pH} 3.36$. This implies that the CYP2C11 assay method is robust, considering the change in mobile phase ratio.

\section{Changing the Column Temperature}

A robustness study was conducted by considering the change in column temperature on HPLC, by evaluating the effect on retention time and peak area of each compound. As $30^{\circ} \mathrm{C}$ was the optimum column temperature for HPLC, thus $25^{\circ} \mathrm{C}$ was selected, as it is $\pm 5^{\circ} \mathrm{C}$. Table 10 shows the effect of temperature on both retention time and peak area of each compound in CYP2C11 assay.

Table 10. Retention time and peak area variation using two different column temperatures.

\begin{tabular}{|c|c|c|c|c|}
\hline $\begin{array}{l}\text { Mobile Phase } \\
\text { Composition }\end{array}$ & Compounds & $\begin{array}{l}\text { Average Retention } \\
\text { Time }(\mathrm{n}=3)(\mathrm{min})\end{array}$ & $\begin{array}{l}\text { Average Area } \\
\text { Peak }(n=3)\end{array}$ & Resolution \\
\hline \multirow{4}{*}{$\begin{array}{c}68 \% \text { Methanol }+32 \% \\
\text { Phosphate buffer at } \\
\mathrm{pH}=3.36 \text { at a flow } \\
\text { rate }=0.8 \mathrm{~mL} / \mathrm{min} \text { and } \\
\mathrm{T}=25^{\circ} \mathrm{C}\end{array}$} & Salicylic acid $(100 \mu \mathrm{M})$ & 3.549 & 50965 & \multirow{4}{*}{$\begin{array}{l}\text { All compounds were well separated from } \\
\text { each other. Difference in retention time } \\
\text { between salicylic acid and phenacetin } \\
\text { was } 1.287 \mathrm{~min} \text {. }\end{array}$} \\
\hline & Phenacetin $(50 \mu \mathrm{M})$ & 4.836 & 135948 & \\
\hline & Testosterone $(200 \mu \mathrm{M})$ & 13.287 & 597882 & \\
\hline & $\begin{array}{l}\text { 16 } \alpha \text { - hydroxytestosterone } \\
\qquad(50 \mu \mathrm{M})\end{array}$ & 6.025 & 184493 & \\
\hline \multirow{4}{*}{$\begin{array}{c}68 \% \text { Methanol }+32 \% \\
\text { Phosphate buffer at } \\
\mathrm{pH}=3.36 \text { at a flow } \\
\text { rate }=0.8 \mathrm{~mL} / \mathrm{min} \text { and } \\
\mathrm{T}=30^{\circ} \mathrm{C}\end{array}$} & Salicylic acid(100 $\mu \mathrm{M})$ & 3.492 & 50536 & \multirow{4}{*}{$\begin{array}{l}\text { All components were well separated from } \\
\text { each other. Difference in retention time } \\
\text { between salicylic acid and phenacetin } \\
\text { was } 1.26 \mathrm{~min} \text {. }\end{array}$} \\
\hline & Phenacetin $(50 \mu \mathrm{M})$ & 4.752 & 136505 & \\
\hline & Testosterone $(200 \mu \mathrm{M})$ & 12.472 & 598229 & \\
\hline & $\begin{array}{l}16 \alpha \text { - hydroxytestosterone } \\
\qquad(50 \mu \mathrm{M})\end{array}$ & 5.854 & 175528 & \\
\hline
\end{tabular}

The peak area and the retention time for each component in the CYP2C11 assay remained unaffected when the temperature was changed from $30{ }^{\circ} \mathrm{C}$ to $25^{\circ} \mathrm{C}$. However, testosterone eluted earlier when the temperature increased from $25^{\circ} \mathrm{C}$ to $30{ }^{\circ} \mathrm{C}$. A temperature of $25^{\circ} \mathrm{C}$ was chosen in this analytical method, because the resolution between salicylic acid and the phenacetin peak (1.287 $\mathrm{min})$ at $25^{\circ} \mathrm{C}$ was greater than the resolution between salicylic acid and the phenacetin peak (1.26 min) at $30{ }^{\circ} \mathrm{C}$. Overall, this method is robust, considering the change in column temperature.

\subsection{Effects of Salicylic acid on CYP2C11 Activity}

Different concentrations of testosterone $(25,50,100,150$ and $200 \mu \mathrm{M})$ were incubated in the presence of $0,50,100$ and $200 \mu \mathrm{M}$ salicylic acid using $0.5 \mathrm{mg} / \mathrm{mL}$ of rat liver microsome with $1.0 \mathrm{mM}$ NADPH (Nicotinamide Adenine Dinucleotide Phosphate Hydrogen), 5.0 mM G6P (Glucose-6-Phosphate), 1.7 units/mL G6PDH (Glucose-6-Phosphate Dehydrogenase), 1.0 mM EDTA (Ethylenediamine tetraacetic acid) and $3.0 \mathrm{mM}$ magnesium chloride and the reaction was terminated at different time intervals. The effect of salicylic acid on CYP2C11 activity is shown in Table 11 and Figures 4 and 5 .

Table 11. Pharmacokinetic parameters of CYP2C11 inhibition study. Values are expressed as mean \pm $\mathrm{SD}(\mathrm{n}=3)$. Note: $p<0.0001$.

\begin{tabular}{|c|c|c|c|c|}
\hline $\begin{array}{c}\text { Pharmacokinetic } \\
\text { Parameters }\end{array}$ & No Inhibitor & $\begin{array}{c}50 \mu \mathrm{M} \text { Salicylic } \\
\text { Acid }\end{array}$ & $\begin{array}{c}100 \mu \text { M Salicylic } \\
\text { Acid }\end{array}$ & $\begin{array}{c}200 \mu \text { M Salicylic } \\
\text { Acid }\end{array}$ \\
\hline$K_{\mathrm{m}}(\mu \mathrm{M})$ & $87.5613 \pm 3.0516$ & $86.5999 \pm 3.0855$ & $83.3333 \pm 3.2064$ & $80.8335 \pm 3.3056$ \\
\hline$V_{\max }\left(\mu \mathrm{M}^{-1} \cdot \min ^{-1}\right)$ & $0.7668 \pm 0.1445$ & $0.6581 \pm 0.1684$ & $0.5000 \pm 0.2216$ & $0.5094 \pm 0.2175$ \\
\hline$C l_{\text {int }}\left(\mu \mathrm{M}^{-2} \cdot \min ^{-1}\right)$ & $0.0087 \pm 0.1228$ & $0.0075 \pm 0.1425$ & $0.0060 \pm 0.1782$ & $0.0063 \pm 0.1697$ \\
\hline$\alpha^{\prime}$ & - & $1.1651 \pm 0.1437$ & $1.5336 \pm 0.1092$ & $1.5052 \pm 0.1112$ \\
\hline$\%$ inhibition & - & $14.1766 \pm 0.6661$ & $34.7967 \pm 0.2714$ & $33.5642 \pm 0.2814$ \\
\hline
\end{tabular}




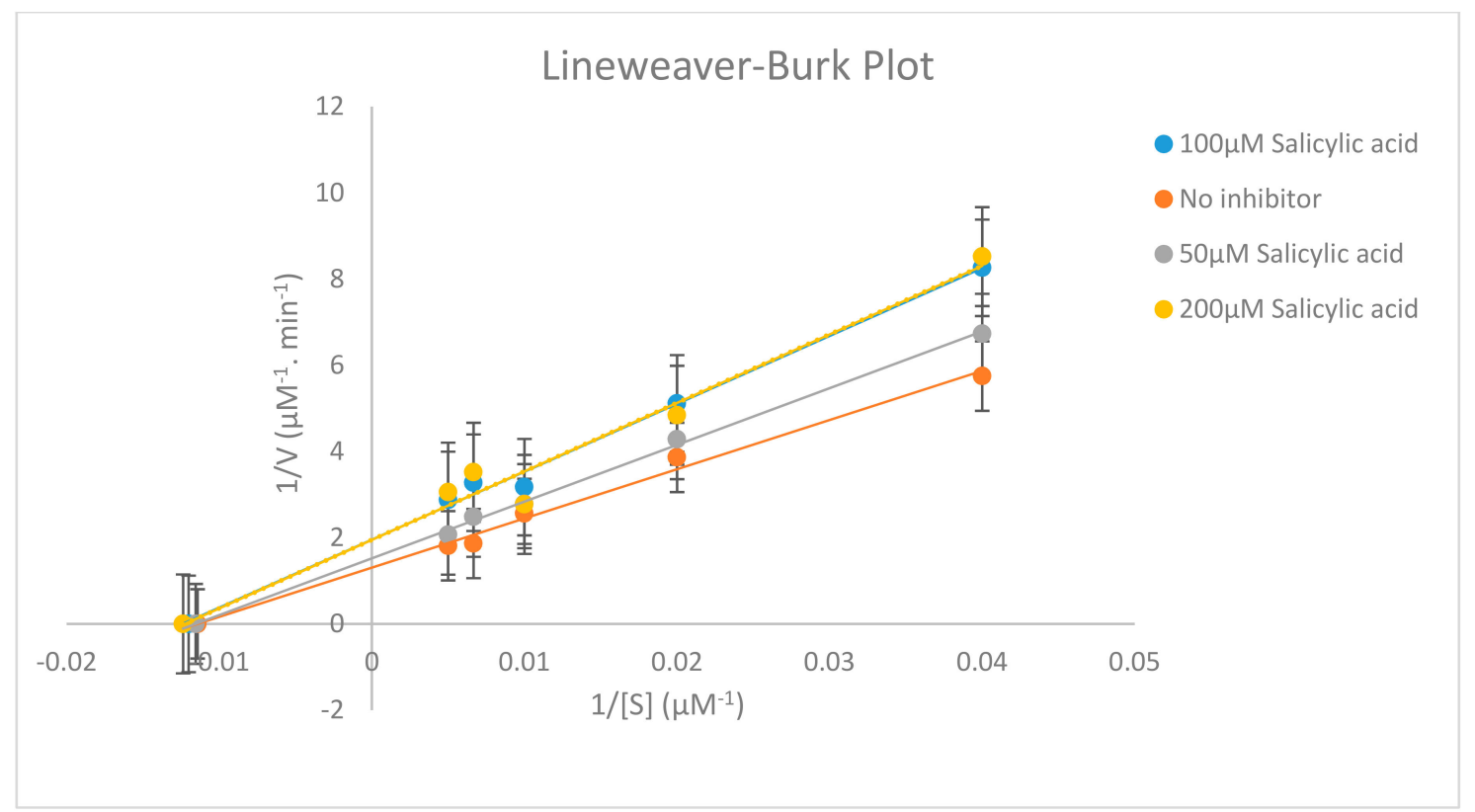

Figure 4. Lineweaver-Burk plot displaying the inhibition of CYP2C11 enzyme on the metabolism of testosterone into $16 \alpha$-hydroxytestosterone using 0-200 $\mu \mathrm{M}$ salicylic acid. Each point represents averages of triplicate determinations.

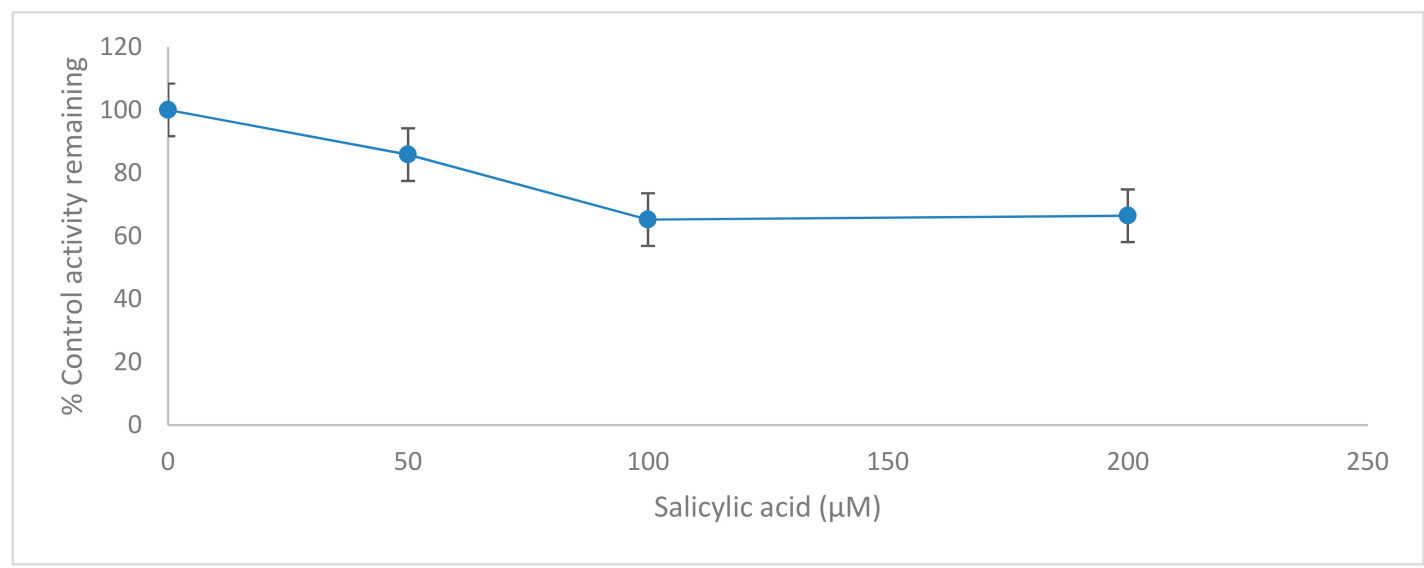

Figure 5. Inhibition of CYP2C11 isoform by salicylic acid $(0-200 \mu \mathrm{M})$ in rat liver microsomes. Data represent averages of triplicates and are expressed as percentage of remaining control activity.

The experimental method for a CYP2C11 assay has been validated in this study for testosterone and 16 $\alpha$-hydroxytestosterone. All the analytical parameters (accuracy, precision, \% error, \% recovery, LOD, LOQ, linear regression) were in line with ICH guidelines.

Our in vitro results demonstrate clearly that salicylic acid, at therapeutically relevant concentrations (0-200 $\mu \mathrm{M})$ [17], acts potently as a reversibly noncompetitive inhibitor, which may inhibit cytochrome P450 2C11 enzyme activity, since the calculated $K_{\mathrm{m}}$ (substrate concentration at which the reaction rate is half of its maximal value) remains unaffected at three salicylic acid concentrations $\left(50,100\right.$ and $200 \mu \mathrm{M}$ ). However, the $V_{\max }$ (maximal rate of the reaction at which enough substrate molecules completely fill the enzyme active sites) for the inhibition studies $(50,100$ and $200 \mu \mathrm{M}$ salicylic acid) decreased compared to the $V_{\max }$ of the negative control assay, as shown in Table 11 and in the supplementary Data (Table S1, Table S2 and Figure S2). This means that salicylic acid as an inhibitor reduces the activity of the CYP2C11 enzyme and is involved in the binding to an allosteric site. Thus, salicylic acid weakly inhibits the CYP2C11 enzyme activity with $\mathrm{K}_{\mathrm{i}}=84.58 \pm 2.67 \mu \mathrm{M}$ (concentration of inhibitor to cause $50 \%$ inhibition of original enzyme activity $\left.\left(\mathrm{IC}_{50}\right)=82.70 \pm 2.67 \mu \mathrm{M}\right)$. A higher 
value of $\mathrm{K}_{\mathrm{i}}$ for salicylic acid in rat liver microsomes has a potentially negligible effect in causing drug interactions with other co-administrated drugs, which are substrates of the CYP2C11 enzyme. Outcomes from this in vitro study looking at the inhibitory effect of salicylic acid on CYP2C11 enzyme activity will be beneficial for a future in vivo study for healthcare screening for the effective use of salicylic acid in clinics and for the safe administration of salicylic acid with other drugs. As salicylic acid metabolism is mediated by two CYP450 enzymes (CYP2C11 and CYP2E1) in rat liver microsomes, so it will be necessary to evaluate the in vitro and in vivo inhibitory effects of salicylic acid on CYP2E1 enzyme activity in humans in order to assess the full effects.

\section{Materials and Methods}

\subsection{Materials}

HPLC analytical reagent grade methanol and acetonitrile were purchased from Sigma Aldrich, Co. (Old Brickyard, Gillingham, UK). Salicylic acid, potassium phosphate monobasic, potassium phosphate dibasic, phenacetin with purity greater than $98 \%$, phosphoric acid $(85 \% \mathrm{w} / \mathrm{w})$, glucose-6-phosphate (G-6-P), glucose-6-phosphate dehydrogenase (G-6-PDH), EDTA (Ethylenediamine tetraacetic acid), $\mathrm{NADP}^{+}$(Nicotinamide Adenine Dinucleotide Phosphate), magnesium chloride $\left(\mathrm{MgCl}_{2}\right)$, testosterone, microsomes from liver pooled from male rats (Sprague-Dawley) (Gillingham, UK) and 16-alfa hydroxytestosterone were purchased from Sigma Aldrich, Co (Old Brickyard, Gillingham, UK).

\subsection{Instrument}

A $570 \mathrm{pH}$ Meter purchased from JENWAY Limited (Beacon Road, Stone, Staffordshire, ST15 OSA, UK) was used. A UV-VIS spectrometry instrument was purchased from VWR International Ltd. (Magna Park, Lutterworth, Leicestershire, LE17 4XN, UK) and UV spectra were obtained using a Bio 100 Cary software from Aglient Technologies LDA (Cheadle Royal Business Park, Stockport, Cheshire, SK8 3GR, UK) and $1 \mathrm{~cm}$ length of quartz cuvette. A Shimadzu LC-2010A HT Module liquid chromatographic system was used (Shimadzu, Tokyo, Japan), combined with a low pressure pump quaternary gradient (series 200 LC (Liquid Chromatography) pump), a degasser, a model series 200 UV-detector, a series 200 Peltier LC column oven for chromatographing the analysed solutions, and a series 200 autosampler. A SUPELCO (Fancy Road, Poole, Dorest, BH12 4QH, UK) C18 column ( $25 \mathrm{~cm}$ $\times 4.6 \mathrm{~mm}, 5 \mu \mathrm{m}$ particle size) was used. The data were processed using Shimadzu HPLC 2 data lab solutions software processing system.

\subsection{CYP450 Assay}

\subsubsection{CYP2C11 Substrate and Its Metabolite}

Validation studies were carried out using a LC-2010A HT Module HPLC system (Shimadzu, Toyko, Japan). Chromatographic experiments were assessed in a low pressure gradient mode. The separation of the four target components (salicylic acid used as a tested inhibitor, phenacetin used as an internal standard, testosterone as CYP2C11 substrate and 16 $\alpha$-hydroxytestosterone as CYP2C11 metabolite) was conducted on a SUPELCO C18 column $(25 \mathrm{~cm} \times 4.6 \mathrm{~mm}, 5 \mu \mathrm{m}$ particle size). The mobile phase for chromatographic separation of the four compounds consisted of $32 \%$ of phosphate buffer solution $(\mathrm{pH}=3.36)$ and $68 \%$ of methanol. The flow rate was set to $0.8 \mathrm{~mL} / \mathrm{min}$, and the oven temperature was $30^{\circ} \mathrm{C}$. A wavelength detection of $243 \mathrm{~nm}$ was used and $10 \mu \mathrm{L}$ solution volume was injected for HPLC analysis. The mobile phase consisted of methanol/phosphate buffer ( $\mathrm{pH} 3.36$ ) $(68 \% / 32 \% \mathrm{v} / \mathrm{v})$, which provided good separation and resolution for the investigated compounds.

\subsubsection{Microsomal Incubations and Treatment Protocol}

CYP2C11 activity was determined using testosterone (substrate) via the formation of $16 \alpha$-hydroxytestosterone (metabolite for CYP2C11 enzyme). Oxidative metabolism of testosterone 
was measured using a NADPH-regenerating system consisting of: $1.0 \mathrm{mM}$ NADPH (Nicotinamide Adenine Dinucleotide Phosphate Hydrogen), 5 mM G6P (Glucose-6-Phosphate), 1.7 units/mL G6PDH (Glucose-6-Phospahe Dehydrogenase), 1.0 mM EDTA (Ethylenediamine tetraacetic acid), and $3.0 \mathrm{mM}$ magnesium chloride. Mixtures were incubated in a final volume of $500 \mu \mathrm{L}$ of NADPH-regenerating system and and a final concentration of $0.067 \mathrm{M}$ potassium phosphate buffer at $\mathrm{pH} 7.4$ using a serial range of testosterone $(25,50,100,150$, and $200 \mu \mathrm{M}$, dissolved in mobile phase) and a serial range of salicylic acid solutions (0, 50, 100 and $200 \mu \mathrm{M}$, dissolved in mobile phase), which were added to the incubation mixture in triplicate. The reaction was initiated by adding $0.5 \mathrm{mg} / \mathrm{mL}$ of pooled liver microsomes to each tube. $\mathrm{NADP}^{+}$(Nicotinamide Adenine Dinucleotide Phosphate) was added to the mixture after pre-incubation of all components for $10 \mathrm{~min}$ in a water bath at $\mathrm{T}=37^{\circ} \mathrm{C}$ [18]. The final concentration of organic solvent did not exceed the $1 \%$ volume. Tubes were incubated for $60 \mathrm{~min}$ in an Eppendorf thermomixer (Eppendorf UK Limited, Stevenage) at $800 \times g\left(37^{\circ} \mathrm{C}\right)$. The reaction was terminated after $65 \mathrm{~min}$ by the addition of ice-cold grade acetonitrile containing $50 \mu \mathrm{M}$ of phenacetin (as an internal standard). Tubes were centrifuged in a microcentrifuge $(13,000 \times g)$ for $12 \mathrm{~min}$ to precipitate protein. Then, the supernatant was collected and dissolved in a mobile phase (30\% phosphate buffer at $\mathrm{pH} 3.36$ and $70 \%$ methanol) and made up to $1000 \mu \mathrm{L}$ volume. A volume of $10 \mu \mathrm{L}$ of dissolved supernatant was injected into the instrument for HPLC analysis.

\subsection{Selection of Analytical Wavelength}

\section{CYP2C11 Assay}

Phenacetin $(50 \mu \mathrm{M})$, salicylic acid $(100 \mu \mathrm{M})$, testosterone $(200 \mu \mathrm{M})$, and $16 \alpha$-hydroxytestosterone $(50 \mu \mathrm{M})$ standard solutions were recorded in the UV region of $200-350 \mathrm{~nm}$ using methanol as a blank, and $243 \mathrm{~nm}$ absorption wavelength.

\subsection{Preparation of Mobile Phase}

\section{CYP2C11 Assay}

Different mobile phases for the CYP2C11 assay were used. Thus, the most suitable mobile phase was as follows: HPLC grade methanol (low UV cut-off of $205 \mathrm{~nm}$ ) as mobile phase (A), and phosphate buffer at $\mathrm{pH}=3.36$ as mobile phase (B) (A: $68 \%, \mathrm{~B}: 32 \%)$.

\subsection{Preparation of Standard and Sample Solutions}

\subsubsection{CYP2C11 Assay}

\section{Analytes Standard Solution Preparation}

Salicylic acid (SA) $(1.38 \mathrm{mg})(\mathrm{C}=200 \mu \mathrm{M})$ was weighed accurately and dissolved in a $50 \mathrm{~mL}$ volumetric flask in a mobile phase $(70 \%$ methanol $+30 \%$ phosphate buffer at $\mathrm{pH}=3.36)$. Serial dilutions were performed, yielding final concentrations of $150,100,75,50,25$, and $10 \mu \mathrm{M}$. Testosterone (5.76 mg) $(\mathrm{C}=400 \mu \mathrm{M})$ was weighed accurately and added to a $50 \mathrm{~mL}$ volumetric flask before being dissolved in mobile phase. A serial dilution of testosterone stock solution was made, yielding final concentrations of 300, 200,150,100, 50, and $25 \mu \mathrm{M}$. Phenacetin was used as an internal standard for the CYP2C11 enzyme assay by dissolving $0.0009 \mathrm{~g}$ of the powder in a mobile phase $(70 \%$ methanol $+30 \%$ phosphate buffer at $\mathrm{pH}=3.36$ ) and a $100 \mathrm{~mL}$ volumetric flask.

\section{Metabolite Standard Solution Preparation}

The metabolite for the CYP2C11 enzyme (16 $\alpha$-hydroxytestosterone) stock solution of $100 \mu \mathrm{M}$ (in a $50 \mathrm{~mL}$ volumetric flask) was prepared, followed by serial dilutions to 80, 60, 40, 20 and $10 \mu \mathrm{M}$ respectively. 


\subsection{Data Analysis}

The regression equation (standard and calibration curves) consisted of different ranges of testosterone and $16 \alpha$-hydroxytestosterone concentrations using $50 \mu \mathrm{M}$ of phenacetin as an internal standard, which was calculated by a weighted least-squares linear regression analysis of mean peak area ratio (peak area of standard/peak area of internal standard) versus standard concentrations. Validation parameters were calculated using Microsoft Excel 2010 software (Microsoft Corp. London, UK).

The CYP inhibition analysis was assessed by measuring the formation of $16 \alpha$-hydroxytestosterone metabolite of the tested CYP2C11 substrate (testosterone). The peak area ratios of both the metabolite and internal standard were acquired using Microsoft Excel 2010 software. Pharmacokinetic parameter $\left(V_{\mathrm{m}}, K_{\mathrm{m}}, C l_{\mathrm{int}}, \alpha^{\prime}, K_{\mathrm{i}}\right)$ values were obtained from secondary Lineweaver-Burk and Michaelis-Menten plots. Inhibition data of CYP2C11 assays were assumed as non-competitive inhibition based on the shape of Lineweaver-Burk plots, and the standard error. AIC (Akaike information criterion) and SC (Schwarz criterion) were from obtained nonlinear regression analysis. The concentration of inhibitor to cause $50 \%$ inhibition of original enzyme activity $\left(\mathrm{IC}_{50}\right)$ was determined by nonlinear regression using Graphpad Prism software (London, UK). The percentage inhibition was calculated from $V_{\mathrm{m}}$ values.

\section{Conclusions}

In conclusion, an HPLC method was developed and validated for high throughput screening of compounds mediated by the CYP2C11 enzyme using salicylic acid as a tested inhibitor. Optimisation for in vitro CYP2C11 enzymatic reaction was achieved with regard to enzyme concentration and incubation time of the reaction. The amount of marker metabolite was quantified by a highly accurate and sensitive HPLC method. In this study, the in vitro CYP2C11 inhibition assay data demonstrated that Salicylic acid acts reversibly as a noncompetitive inhibitor, which may inhibit cytochrome P450 2C11 enzyme activity. The outcomes obtained provide useful tips for the effective use of salicylic acid in clinics. However, further in vitro and in vivo investigational studies are needed to determine the effect of salicylic acid administration in humans for full healthcare screening, regarding the safety of this drug when administrated concomitantly with regular medicines.

Supplementary Materials: The following are available online, Figure S1: UV-VIS spectroscopy for Phenacetin (internal standard) in the CYP2C11 assay, Table S1: Linear regression, range and limit of detection analysis for CYP2C11 assay incubation, Table S2: Outcomes of rat microsomal incubation assays $(\mathrm{n}=3)$ of 60 min incubation using different range of Testosterone concentration levels, Figure S2: Bar chart shows the reduction in Testosterone and the formation of 16-alfa hydroxytestosterone after $60 \mathrm{~min}$ of CYP2C11 assay incubation at different testosterone concentration levels $(25,50,100,150,200,300$ and $400 \mu \mathrm{M})$.

Author Contributions: All authors designed, conceived and performed the experiments. Formal data analysis, interpretations and writing of the original draft were performed by all authors. The final manuscript was edited, reviewed, and approved by all authors.

Funding: This research received no external funding.

Acknowledgments: We thank Siamak Soltani-Khankahdani and Paul Stovell from Kingston University for their technical assistance.

Conflicts of Interest: The authors declare no conflict of financial interest or any financial involvement with any company.

\section{References}

1. Zanger, U.M.; Schwab, M. Cytochrome P450 enzymes in drug metabolism: Regulation of gene expression, enzyme activities, and impact of genetic variation. Pharmacol. Ther. 2013, 138, 103-141. [CrossRef] [PubMed]

2. Elfaki, I.; Mir, R.; Almutairi, F.M.; Duhier, F.M.A. Cytochrome P450: Polymorphisms and roles in cancer, diabetes and atherosclerosis. Asian Pacific J. Cancer Prev. 2018, 19, 2057-2070.

3. Lynch, T.; Price, A. The effect of cytochrome P450 metabolism on drug response, interactions, and adverse effects. Am. Fam. Physician 2007, 76, 391-396. [PubMed] 
4. Furge, L.L.; Guengerich, F.P. Cytochrome P450 enzymes in drug metabolism and chemical toxicology: An introduction. Biochem. Mol. Biol. Educ. 2006, 34, 66-74. [CrossRef] [PubMed]

5. Curioni, O.A.; de Carvalho, M.B.; Dedivitis, R.A.; Rapoport, A.; Gattas, G.J.F. The Influence of Gene Polymorphisms on Tobacco and Alcohol-Induced Oral Cancer Risk. J. Cancer Ther. 2013, 04, 978-988. [CrossRef]

6. McDonnell, A.; Dang, C. Basic Review of the Cytochrome P450 System. J. Adv. Practitioner Oncol. 2013, 4, 263-268.

7. Wójcikowski, J.; Haduch, A.; Daniel, W.A. Effect of antidepressant drugs on cytochrome P450 2C11 (CYP2C11) in rat liver. Pharmacol. Rep. 2013, 65, 1247-1255. [CrossRef]

8. $\quad$ Bigler, J.; Whitton, J.; Lampe, J.W.; Fosdick, L.; Bostick, R.M.; Potter, J.D. CYP2C9 and UGT1A6 genotypes modulate the protective effect of aspirin on colon adenoma risk. Cancer Res. 2001, 61, 3566-3569. [PubMed]

9. Doi, H.; Horie, T. Salicylic acid-induced hepatotoxicity triggered by oxidative stress. Chem. Biol. Interact. 2010, 183, 363-368. [CrossRef] [PubMed]

10. Li, J.P.; Guo, J.M.; Shang, E.X.; Zhu, Z.H.; Liu, Y.; Zhao, B.C.; Zhao, J.; Tang, Z.S.; Duan, J.A. Quantitative determination of five metabolites of aspirin by UHPLC-MS/MS coupled with enzymatic reaction and its application to evaluate the effects of aspirin dosage on the metabolic profile. J. Pharm. Biomed. Anal. 2017, 138, 109-117. [CrossRef] [PubMed]

11. Kasuya, F.; Kazumi, M.; Tatsuki, T.; Suzuki, R. Effect of salicylic acid and diclofenac on the medium-chain and long-chain acyl-CoA formation in the liver and brain of mouse. J. Appl. Toxicol. 2009, 29, 435-445. [CrossRef] [PubMed]

12. Kumar, V.P.; Gupta, N.V. A review on quality by design approach (QBD) for pharmaceuticals. Int. J. Drug Dev. Res. 2015, 7, 52-60.

13. Li, X.F.; Ma, M.; Cheng, A.; Zheng, J.; Tam, Y.K. Determination of testosterone and its metabolites using liquid chromatography with elevated column temperature and flow-rate gradient. Anal. Chim. Acta 2002, 457, 165-171. [CrossRef]

14. Eagling, V.A.; Tjia, J.F.; Back, D.J. Differential selectivity of cytochrome P450 inhibitors against probe substrates in human and rat liver microsomes. Br. J. Clin. Pharmacol. 1998, 45, 107-114. [CrossRef] [PubMed]

15. Alvi, S.N.; al Dgither, S.; Hammami, M.M. Development and validation of LC-MS/MS method for determination of testosterone level in human saliva using lovastatin as internal standard. J. Bioequiv. Bioavailab. 2013, 5, 228-232.

16. Purdon, M.P.; Lehman-McKeeman, L.D. Improved high-performance liquid chromatographic procedure for the separation and quantification of hydrotestosterone metabolites. J. Pharmacol. Toxicol. Methods 1997, 37, 67-73. [CrossRef]

17. Mulholland, J.W. SCCNFP, SCCNFP052201 (salicylic acid). Perfusion 2008, 23, 309. [CrossRef] [PubMed]

18. Sun, M.; Tang, Y.; Ding, T.; Liu, M.; Wang, X. Inhibitory effects of celastrol on rat liver cytochrome P450 1A2, 2C11, 2D6, 2E1 and 3A2 activity. Fitoterapia 2014, 92, 1-8. [CrossRef] [PubMed]

Sample Availability: Samples of the compounds are not available from the authors.

(C) 2019 by the authors. Licensee MDPI, Basel, Switzerland. This article is an open access article distributed under the terms and conditions of the Creative Commons Attribution (CC BY) license (http://creativecommons.org/licenses/by/4.0/). 